International Journal of Instruction

e-ISSN: 1308-1470 • www.e-iji.net
July $2019 \bullet$ Vol.12, No.3

p-ISSN: 1694-609X

pp. $151-166$

Received: 01/06/2018

Revision: 22/03/2019

Accepted: 28/03/2019

OnlineFirst:22/04/2019

\title{
Adventure Learning in Basics Statistics: Impact on Students Critical Thinking
}

\section{Mohd Afifi Bahurudin Setambah}

Research and Development Department, IPG Kampus Bahasa Melayu, Malaysia, mohdafifi@ipgkbm.edu.my

\section{Nor'ain Mohd Tajudin}

Mathematics and Sciences Faculty, Sultan Idris Education University, Malaysia, norain@fsmt.upsi.edu.my

Mohd Faiz Mohd Yaakob

Universiti Utara Malaysia, Malaysia,mohd.faiz@uum.edu.my

\section{Muhamad Ikhwan Mat Saad}

Kementerian Pendidikan Malaysia, Malaysia,aey505@gmail.com

$\mid$

Malaysia Ministry of Education has put critical thinking skills elements into one of the six aspirations that pupils need to achieve. This was a turning point that teaching methods should be transformed. Therefore, innovation of teaching methods needs to be done. One of the strategies suggested is adventure-based learning (ABL). The main objective of this study is to examine the impact of ABL methods in the teaching of Basic Statistics on critical thinking skills. This study uses a quantitative approach with quasi experimental pre and post design. Only one group of students is formed. The study was based on the cluster sampling method and involving the semester two students of the Preparation Programme of Teaching Bachelor (PPTB). Instruments used are modules of adventure-based teaching methods and critical thinking skills tests. The findings of this study are to prove that this adventure-based learning can be used as an alternative method to assist the lecturers of the Teacher Education Institute to produce credible graduates. It helps lecturers apply the 21 st century learning method in their teaching and learning.

Keywords: adventure-based learning, fun learning, quasi-experimental design, critical thinking, basics statistics, mathematics education

\section{INTRODUCTION}

Every born child, endowed with great potential and extraordinary talent. The potential and talent will be achieved with ongoing development through education. Thus, teachers 
should provide interaction space, positive environment and apply various methods of teaching and learning that can shape the potential of the child. This is in line with the National Education Philosophy that is to develop balanced people to an optimum level (Azhari \& Zaleha, 2013).

In line with that, the Malaysia Ministry of Education (MOE) under a National Education Philosophy wishes to create a comprehensive humanity from physical, emotional, spiritual, intellectual and personality aspects. Changes made by MOE are in line with current developments and demands. Various skills need to be provided and applied to students to enable them to be competitive and have added value, thus enhancing their potential and talent at the highest level. Neighboring countries such as Singapore have been implementing teaching and learning of Higher-Level Thinking Skills (HOTS) since 1997 (Yeo \& Zhu, 2005). This is evidenced by the achievement of the country in the Tests of Trends in International Mathematics and Science Study (TIMSS) and the Program for International Student Assessment (PISA) where they have occupied the top five in both assessments. While in Malaysia, thinking oriented teaching has begun in the early 1990's (Rajendran, 2010). However, the performance of the country is still not at the good level.

The Creative and Critical Thinking Skills were introduced in 1989 after the new curriculum was implemented in Malaysia. In general, the country has long been exposed to thinking skills in teaching and learning. However, teachers still did not make any changes in implicating thinking skills during teaching and learning but implemented it separately (Yee, Jailani, Widad, Razali, \& Tee, 2010). Mathematics teachers are still using lecture methods, individual work (training), and revision of answers in their class (Yeo \& Zhu, 2005). They are also do more practicing exercises and focus to finish subject syllabus (Azhari \& Zaleha, 2013, Koh, Choy, Lai, Khaw, \& Seah, 2008). Teachers are also emphasizing the examination only (Wan Nor Atiqah \& Muzirah, 2016). Teaching methods used by teachers should change according to the changing educational system required in line with government policy as well as global level changes. Through the National Education Blueprint (PPPM), 2013-2025 (Ministry of Education, 2013) has outlined a number of student aspirations to be achieved through education. The main thing to focus on is the aspect of student outcomes.

Six aspirations have been outlined to improve student outcomes. The aspirations that need to be developed are the aspects of student knowledge, the ability of students to use at least two languages, leadership skills, critical thinking skills, ethics and spirituality, and have a national identity (Ministry of Education, 2013). Therefore, the selection of appropriate teaching methods should be done. A method of teaching has been identified as possibly able to shape the pupil's identity. It is known as an adventure-based learning (ABL) method. Weilbach, Meyer and Monyeki (2011) as well as Scrutton and Beames (2013) assume that the ABL is an appropriate method for developing personalities and social groups. In addition, ABL are often used in various areas to enhance individual interpersonal and intrapersonal skills in leadership (Rhodes \& Martin, 2013; Sutherland $\&$ Stuhr, 2012). In fact, ABL views as a multidimensional learning approach in which it combines the various aspects of intellect, ethics, physical, and spiritual (Larson, 2010). 
In addition, the main goal of $\mathrm{ABL}$ is to carry out teaching and learning sessions that include cognitive, psychomotor and affective domains (Ford, 1986). The ABL is also a learning method that emphasizes the fun learning concept, student-centered strategy, linking the content of the lesson to everyday life situations and giving a meaningful experience (Mohd Afifi, Nor'ain \& Mazlini, 2016). However, the impact of the ABL method is still poorly studied in terms of critical thinking skills. Hence, this study looks to what extent the ability of the ABL method to improve students' critical thinking skills while studying Basic Statistics.

\section{REVIEW OF LITERATUR}

\section{Adventure Based Larning}

The ABL has basically been around for so long. This educational history begins with the establishment of Outward Bound by Kurt Han in 1941. The mission of setting up a school in Aberdovey, Wales is to enhance confidence, perseverance and build experience for young sailors. The ABL is defined as an out-of-class activity, has an adventure element and involves learning (Sibthorp \& Jostad, 2014). This method generally uses elements such as out-of-school education, camping and physical education (Mohd Afifi, Nor'ain \& Mazlini, 2016). This method has the basic features of learning theory based on Kolb's experience in 1984 (Cooley et al., 2014; Hans, 2000; Hogson \& Berry, 2011) and Dewey's inquiry-based learning was introduced in 1938 (Doering, 2007; Mohd Afifi, Nor'ain \& Mazlini, 2016; Veletsianos \& Kleanthous, 2009). However, there is still a lack of research that the ABL only involves the combination of the two approaches. This is in line with the opinions expressed by Veletsianos and Kleanthous (2009), where research on ABL is still ongoing and the theory used as the basis for this method is still being discussed.

ABL is a subset of experiential learning (Cooley et al., 2014; Hans, 2000; Hogson \& Berry, 2011; Larson, 2010). The ABL is also seen from the aspect of outside classroom learning (Bunyan, 2011; Hogson \& Berry, 2011). According to Bunyan (2011), ABL environment is composed of certain ingredients. It requires support groups, leadership, physical training, mental strength and natural environment. Doering (2006) has highlighted seven principles on this ABL. Principles of ABL are as follows:

a. Research and inquiry curriculum.

b. Opportunities for collaboration and interaction among students, teachers and experts.

c. The use of the internet as a learning medium.

d. Media and text can be delivered on time.

e. Synchronization in educational opportunities.

f. Have guidelines on implementation of online curriculum pedagogy.

g. Adventure based activities.

Implementation of the ABL should take into account all of the above principles. Study and inquiry curriculum are the first principle of ABL. This principle requires us to highlight the concept of problem-solving learning that involves active participation by students. The second principle is the opportunity to collaborate between students, teachers and experts. This principle means during the learning process using the ABL 
method, the interaction between students, students and students is needed. The third and fourth principles are the use of the internet as a medium of learning and the media and texts to be delivered in due course are closely related. This principle prioritizes the concept of information sharing through mediums such as smartphones or laptops. Thus, the use of the internet as a medium of media and textual sharing. The next principle is the consistency in educational opportunities that mean that students are able to share and ask any learning problems through medium or group sites that have been developed such as group telegram or Facebook group. Sixth is to have pedagogical guidance guide. The guide is made so that teachers using this method can develop the medium or site of the group mentioned above. The final principle is adventure-based activities. Therefore, adventure activity is needed during the teaching and learning session. Example of adventure activities is explore race, flying fox, bicycle and many more.

The implementation and planning of the ABL should be done as traditional teaching and learning. Therefore, learning outcomes must be established first. This has also been emphasized by Doering (2006). According to him, identifying learning outcomes is a key aspect before planning ABL activities. This method is not putting adventure and exploration as a goal, but learning. Berry (2011) states that the implementation of the ABL method should take into account several elements such as participants, group size, teacher character, environment, activity and process of the ABL itself. These elements need to be considered for the best results.

Veletsianos (2012) proposes two possible ABL situations. First group of students perform adventure activities, collecting related data. The data is then shared through online learning. While the rest of the teacher and colleagues are in the classroom doing the investigation on shared data. They conducted discussion sessions with each other until the curriculum goals were achieved. For the second situation, teachers and all students go beyond the classroom activities. The information collected by the adventure group is then shared with different classes. Both of these situations essentially need to make inquiry-based approaches and experiential learning as the mainstay.

The success of performing adventure activities is influenced by group collaboration. Rarely seeing this rugged activity is done alone. Then the interaction between the participants or students is very important. Interactions within the ABL are influenced by the social learning system. There are eight aspects that affect the social interaction system in the ABL environment. Among them are contextual macro (beliefs, cultures and organizational structures), students, teachers, goals, groups, group results, individual results in groups and times (Sibthorp \& Jostad, 2014).

In conclusion, the $\mathrm{ABL}$ provides the environment that teachers need during teaching and learning. This will help teachers to implement student-centered teaching and learning. Teacher, student and specialist interactions are needed to help students achieve the desired learning outcomes. Therefore, all aspects to be considered need to be considered. However, ABL interactions in the context of the study are conducted faceto-face. Interactions via smartphones are also used. This interaction involves only two parties, students and facilitators. 


\section{Mini ABL Implementation Guide}

The ABL is currently in great measure, scope, duration and funding (Veletsianos \& Kleanthous, 2009). This approach is often practiced in social sciences in some places. This approach can also be applied in the field of education, various locations and subjects. Implementation of ABL on a smaller scale is also recommended (Veletsianos \& Kleanthous, 2009). This gives the understanding that ABLs can also be practiced by teachers for all subjects. The literature review shows that teachers need to focus on four different elements to create a ABL environment curriculum, activity, standards and media (Miller, Hougham \& Eitel, 2008). According to Miller, Veletsianos, and Doering (2013), using media such as android phones and digital cameras is sufficient to create a ABL environment. The integration of the four elements will motivate, excite and delight the learning atmosphere of the ABL. The study conducted by Doering and Veletsianos (2008) found that students enjoyed participating in the ABL, exhibiting behavioral changes in the programme and discussing ABL outside the classroom.

Despite still less ABL implementation in the small scope. Riggins (1986) proposes several factors that influence the effectiveness of the ABL environment. As a result of his research, there are five important factors that have been identified, namely the number of small group of students, the cooperative learning environment, the communication between students, the focus on the successful completion of the assignment and the creation of positive culture such as supporting each other. These factors need to be emphasized during ABL activities so that the effectiveness studied can be improved. In addition, there are other recommended guides. Veletsianos (2010) has been instructing the implementation of $\mathrm{ABL}$ in teaching and learning. His $\mathrm{ABL}$ implementation guide is as follows:

i. Determine the issue or problem that the student wants to solve.

ii. Identify locations, populations and experts on issues.

iii. Develop a curriculum and the design of an online environment that involves collaboration.

iv. Exploring selected locations and collecting curriculum-related data.

v. Share the data collected online and lead to curriculum goals.

vi. Collaboration between students in the classroom and beyond to explore and learn ABL.

According to Larson (2010), one of the activities that can be undertaken as an adventure activity is to provide students with daily tasks. For example, students are asked to go to the grocery store, making purchases in cash and negotiating prices in the purchase. While according to Karppinen (2012), the ABL is different from traditional teaching where teachers and students will participate in planning and realizing goals. The theme of mutual discussion needs to be applied in teaching and learning.

This ABL method requires detailed planning. It involves a safety risk for students. The selection of appropriate activities should also be examined. It is critical to enable the final outcome of teaching and learning sessions to be achieved as desired. If the selected activity is too easy, the student will be bored. Meanwhile, if the activity is very 
challenging, then students will be worried about joining it (Stuhr et al., 2016). Therefore, the implementation of teaching and learning with this ABL method should focus on the selection of activities.

In conclusion, the $\mathrm{ABL}$ is a method that gives students the opportunity to experience learning in the realm of the world, collaborating on technology and participated by various parties, students, teachers and experts. This approach supports the theory of experiential learning and an inquiry-based approach (problem solving). This method is specially designed to develop and diversify learning strategies. However, the ABL can be implemented in some ways whether classroom learning, project-based, virtual-world technology or combination of these rules. In the context of the study, the ABL is conducted in accordance with the developed module. The development of the module has taken into consideration the elements discussed above.

\section{The Benefits of $A B L$}

Generally, the teaching and learning approach affects students. Careful planning will provide optimum impact. Mohd Taib and Norlena (2010) stated that this approach was able to create unity, and integration between groups. Through the activities participated, students began working as a team, helping each other, having friendship, cooperation and tolerance. He and his colleagues conducted a quasi-experimental study of 671 students comprising prospective teachers from the University and Teacher Education Institute throughout Malaysia. Participants are then divided into control groups and treatment groups. By using the pre-test "Life Effectiveness Questionnaire" test, post exams and post exams are given to the participants. Constructs assessed are related to psychology and behavior namely cooperative, leadership skills, self-confidence and willing to face change. The findings show that there is a significant difference to the constructed constructs. The findings were then analyzed using Cohen $d$ to evaluate how far the impact of adventure education on constructs. The result shows that adventure education contributes 34 percent (cooperative), 53 percent (self-confidence), 60 percent (Leadership ability) and 61 percent (ready for change). It has also been confirmed that there is a significant difference between students participating in the program and not participating in the ABL program for self-development (Fadhilah, Hamid, \& Mohamed 2016).

The ABL is seen to have an impact on the student's self-development. This is supported by studies in the field of counseling and psychology. Human (2012) conducted a study on 19 post-graduate students. Four men are men and 15 women. The selected students use the purposive sampling process. The study aims to describe the improvement of student self-development through adventure activity. The division of two groups, the control group and the treatment group, was conducted. One day activity from 7.00 am to $10.00 \mathrm{pm}$ was carried out. As a result of these activities, there has been an increase in self-development after the activity has taken place. This is assessed based on the reflection of the writing. The data were analyzed based on Duquesne Phenomenological Research Method (DPRM) in interpersonal and intrapersonal aspects. In addition, a selfdevelopment and professional module was developed by researchers from National University of Malaysia. The module contains three external activities that emphasize 
teamwork and leadership. A survey on the perception of 222 medical course students was conducted. Pre questionnaire was given before the activity took place. Post questionnaire was given after activity. In general, there is a change of perception before and after the activity (Juriza et al., 2011).

Anderson (2014) notes that the PBA is seen as an ideal educational tool for selfdevelopment in many aspects. The aspect is personal development, morals, groups and leadership. One meta-analysis has been made regarding the results of this PBA. The meta-analysis is conducted with size of effect 1.728. This is illustrated from the 151 samples representing 96 studies. The average effect size at the end of the adventure program is 0.34 . Analysis shows that there are 40 PBA effects on students. However, the effects are grouped into six categories. PBA has impacted on academic aspects, leadership, self-concept, personality, self-esteem and interpersonal (Hattie, Marsh, Neill, $\&$ Richards, 1997). PBA results are also reviewed by Cooley with friends. The PBA methodology is seen as a result of leadership, communication, trust and decision making (Cooley, Burns, \& Cumming, 2015; Weilbach et al., 2011).

Carrier, Tugurian, and Thomson (2013) conducted a study on ABL. He and his colleagues have implemented mixed methods where quantitative methods aim to test the impact of $\mathrm{ABL}$ on student achievement in science, attitudes and comfort in an environment of external education. While qualitative methods are collected based on interviews with principals, teachers and students. One of the instruments used is the assessment of science knowledge. The results of the pre and post-test analysis for the test found that there was a significant difference between the pre and post-intervention students with t-test value $\mathrm{t}=7.81 ; \mathrm{p}<0.001$. This proves that the $\mathrm{ABL}$ is able to improve its achievement from academic aspects.

In addition, the PBA is seen to benefit the relationship between students. Familiarity with friendships can be strengthened while following activities outside the classroom. This approach is seen as a fun approach where students do not have to sit in chairs and desks, hear lectures from teachers or lecturers, write and read only, but this approach opens up opportunities for students a fun experience. Students also have the opportunity to be out of class while applying learning in real life. Hence, students no longer feel mathematics as something that has nothing to do with the realm of reality (Larson, 2010). The ABL is also seen as a holistic impact. It also provides various learning experiences and transfer the learned knowledge into everyday life (Karppinen, 2012).

For thinking skills elements, problem solving, a study was conducted on the impact of adventure approaches on self-esteem. One of the elements tested is problem solving. Quantitative and qualitative mix studies were carried out in quasi-design quizzes pre, post and postings were carried out. The quantitative study showed no significant difference between treatment groups and control groups in pre-test, post and post-test. However, qualitative data shows that there are elements of problem solving developed based on activities carried out (Beightol, Jevertson, Carter, Gray, \& Gass, 2012).

Thus, the ABL is seen as an appropriate approach used by teachers, lecturers or educators to develop human capital. This is supported by the results of previous studies 
which emphasize student self-development through outdoor activities or adventure learning. Students are reported to have developed a variety of skills in group work, adaptability, diligence, planning, problem solving, time management, communication, leadership, collaboration, and team spirit. In addition, ABL also benefits physical activity, self-confidence, self-awareness, and strengthens peer relationships (Cooley et al., 2014). In fact, there are many benefits of ABL on student learning outcomes, especially in the aspects of social and self-development of students (Stuhr et al., 2016). Implementation of this approach is expected to produce students who master the content of the lesson. In addition, it can also apply other skills in forming first-class human capital. This is in line with the country's mission and aspirations that have been set on students.

\section{ABL Conclusion}

In short, the change and innovation of education approaches should be done in line with global development. Student-centered teaching and learning, based on technology, experience-based and giving students the opportunity to explore and investigate is the scope of the PBA. Students have the opportunity to use the space provided in the PBA environment to communicate, write and transmit views. Communication within the scope of PBA for researcher studies has two approaches namely face-to-face and nonface-to-face. The process of teaching and learning within the scope of an adventurebased study is carried out based on the elements of classroom learning. Students also experience learning in the realm of reality and can share experiences with their other colleagues. This means that students experience the learning of mathematics by completing the assignment given while enjoying the adventure adventure that has been arranged.

Teachers no longer provide direct solutions, but the teacher's function in this research program is as facilitator. Collaborative space between students, teachers and experts should be created as an idea sharing space, giving opinions, discussions and asking questions. Students are given flexible flexibility during the teaching and learning process. The use of these two approaches simultaneously provides an opportunity for students to learn actively where it can fill the diversity of learning styles that exist amongst students. For example, there are a handful of students who are ashamed to ask face to face. Therefore, the virtual space is provided to fill the needs of the students and vice versa. This is based on the Doering model 2006.

The ABL also benefits the development of individuals and organizations. This is reflected in the literature review of the past study. Many ABL studies have shown a positive impact. However, there is less ABL study in the context of mathematical education. It is hoped that this ABL literature review opens the mind of other researchers to further expand the scope of the study on the field of teaching. The development of research in this area, especially in mathematics education, is the basis of the transformation of teaching methods. This is especially important in order for the mission and aspirations of the country to be achieved successfully. 


\section{METHOD}

The purpose of this study is to examine the effect of the ABL method on critical thinking skills. Therefore, the selection of experimental methods using quantitative approaches is appropriate. The selection of experimental methods is accurate if one study seeks to see the relationship between cause and effect (Chua, 2006; Fraenkal, Wallen, \& Hyun, 2012; Gay, Mills, \& Air, 2009). The quasi-experiment design was selected to test the effectiveness of the use of the developed ABL method. It is supported by Chua (2006) which states that the design of the experimental study is specially designed to evaluate the effectiveness of the effects of a program ie the module in the context of the study.

This research also conducted a second post test after eight weeks of first post test was given. The test is called a delayed posttest. The duration of the study was in line with the study conducted by Lee (1997) and Paquette, Brassard, Guerin, Fortin-Chevalier, and Tanguay-Beaudoin (2014). This test aims to see how far the knowledge and skills gained in teaching and learning can be maintained over a long period of time. This test is carried out to fill the vacancy of the study which tests the impact of ABL on long-term variables (Cooley et al., 2015). Additionally, according to Novak (1998), most memorizing lessons in school will disappear within eight weeks. So, any information that can be maintained after that period is considered as meaningful learning. So, the setting of the period is considered to be accurate to test the level of knowledge retention and skills learned during teaching and learning.

The research design is illustrated in detail as Figure 1.

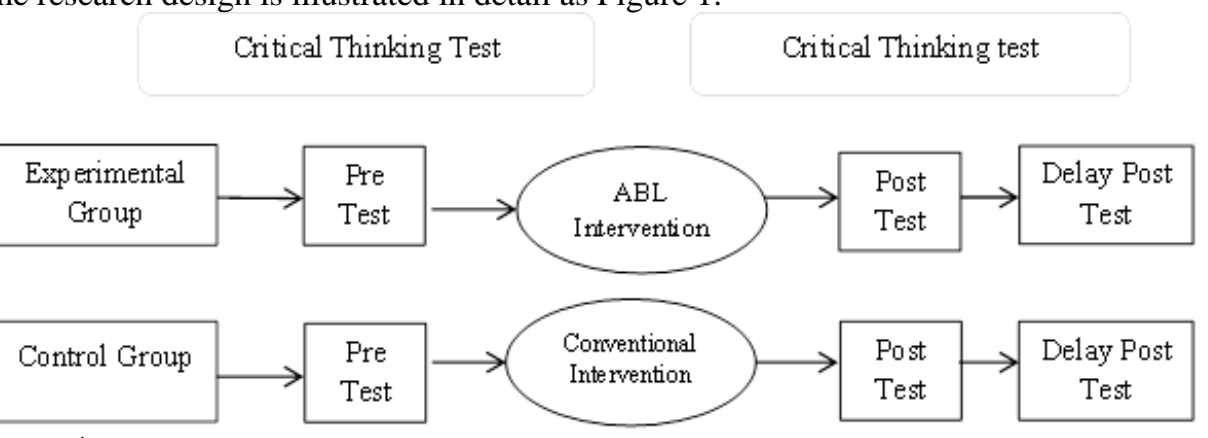

Figure 1

Research Design

In summary, students are grouped into two groups. At the beginning of the study, the students will be explained in detail the purpose of the study. Next, the test is administered. This test is using critical thinking skills test in mathematical context. This is done to assess and determine the level of critical thinking skills students before the intervention. After that, ABL session using the modules is implemented. This module has good validity and reliability (Mohd Afifi, Nor'ain, Mazlini, 2017). This process takes about 10 weeks. Completed intervention, respondents were given posttest. After 8 weeks of posttest, second posttest is given. This post-test is called a delayed posttest. 
This test aims to test the impact of ABL on a longer term. Data were analyzed using ANOVA test.

\section{FINDINGS}

The results of the ANOVA analysis showed that there was no significant difference in the pre- test of critical thinking skills between the treatment group and the control group $[\mathrm{F}(1,28)=1.49, \mathrm{p}>0.05]$ through Table 1 . This proved that the critical thinking skills of both groups is the same in the beginning of the experiment. The comparison of the pairs showed a negative difference in critical thinking skills between experimental groups and control groups (mean $=-2.20$ ). This implies that the control group's critical thinking skills are better than the experimental group. However, Table 2 shows the results of a one-way ANOVA test analysis to determine the difference between the critical thinking skills post test between the experimental group and the control group. The findings of the ANOVA analysis showed that there was no significant difference between the experimental group of critical thinking skills between the experimental group and the control group $[\mathrm{F}(1,28)=0.41, \mathrm{p}>0.05]$. Therefore, the critical thinking skills of both groups are considered equal.

Table 1

Analytical test of ANOVA Differential Pre-critical Thinking Skills Test between Treatment Groups and Control Groups

\begin{tabular}{|c|c|c|c|c|c|c|}
\hline \multicolumn{7}{|c|}{$\begin{array}{l}\text { Univariate Test } \\
\text { Dependent variable: Pre Critical Thinking Test }\end{array}$} \\
\hline+2 & & $\mathrm{df}$ & Mean Square & $F$ & Sig. & Partial Eta Squared \\
\hline Difference & 99.615 & 1 & 99.615 & 1.485 & .233 & .050 \\
\hline Error & 1878.815 & 28 & 67.101 & & & \\
\hline
\end{tabular}

* Significant at the level of confidence $\mathrm{p}<0.05$

Table 2

Analytical test of ANOVA Differential Post-critical Thinking Skills Test between Treatment Groups and Control Groups

Univariate Test

Dependent variable: Post Critical Thinking Test

\begin{tabular}{lllllll}
\hline & Sum of Square & $\mathrm{df}$ & Mean Square & F & Sig. & Partial Eta Squared \\
Difference & 36.300 & 1 & 36.300 & .414 & .525 & .015 \\
Error & 2453.867 & 28 & 87.638 & & &
\end{tabular}

* Significant at the level of confidence $\mathrm{p}<0.05$

One-way ANOVA test results (subject-tested effects) show that overall the difference in critical thinking skills between the two groups. So the researcher rejected the null hypothesis and decided that there was a significant difference in critical thinking skills between the experimental group and the control group. The mean value of the critical thinking skills of the experimental group is better than the control group. The couple's comparison result shows a difference of 5.71 marks between the two groups. Table 3 univariate tests confirm results in comparison of pairs $[\mathrm{F}(1,28)=5.30, \mathrm{p}<0.05]$. The findings also show a large size of impact (Cohen et al., 2007) ie the partial value of that square is 0.159 . The findings suggest that students' critical thinking skills are still at a 
good level for both groups (Sabaria, 2003) although no input is given within eight weeks. However, finding shows that experimental groups are able to keep the skills longer than the control group.

Table 3

ANOVA Test for Post Delay Test between Two Group

Univariate Test

Dependent variable: Delay Post Critical Thinking Test

\begin{tabular}{|c|c|c|c|c|c|c|}
\hline & Sum of Square & $\mathrm{df}$ & Mean Square & $\mathrm{F}$ & Sig. & Partial Eta Squared \\
\hline Difference & 244.626 & 1 & 244.626 & 5.302 & .029 & .159 \\
\hline Error & 1291.970 & 28 & 46.142 & & & \\
\hline
\end{tabular}

* Significant at the level of confidence $\mathrm{p}<0.05$

Figure 2 shows the result of experimental group versus control group for post-test and delayed post-test. The test results of the control group were not better than the experimental group during the post-test. But, when the delayed post-test given, the result show experimental group became better than control group. This shows that ABL's method is able to influence students' critical thinking skills for longer periods of time.
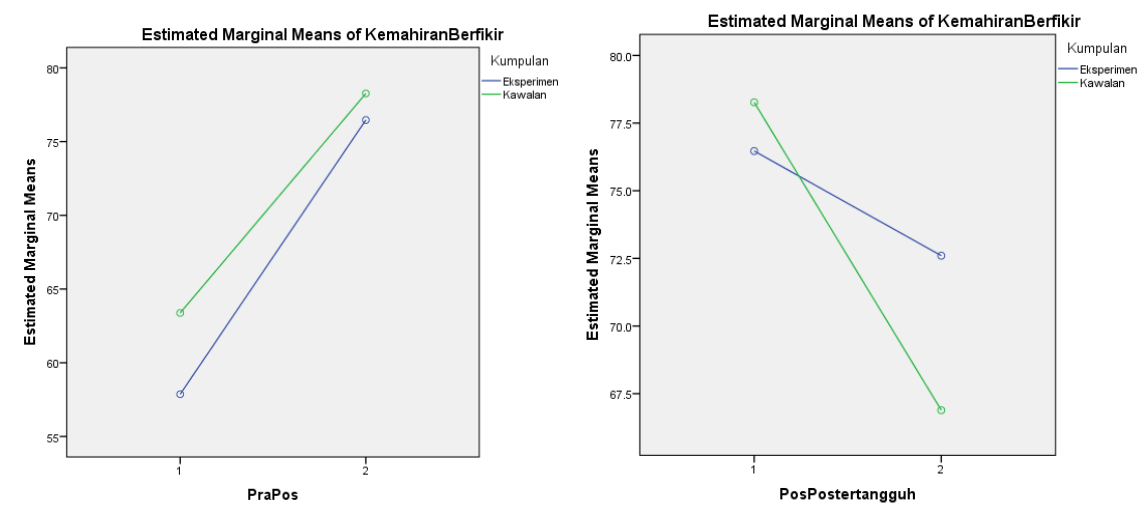

Figure 2

Experimental versus Control Group

\section{CONCLUSION}

In conclusion, this experimental study has proven that this alternative method is ABL capable of affecting students' critical thinking skills. The experimental process is carried out by giving pre-test critical thinking skills to students. The next student was given intervention for 10 weeks. Once completed, a post test is given. Post-test postponement is also given to students after 8 weeks post-test is given.

The findings show that $\mathrm{ABL}$ has a good impact on this element compared to conventional groups. The results obtained in the first post-test indicate no difference between the two groups. However, after 8 weeks, the thinking skills of both groups showed a change. this is evidenced by the findings of the postponed postponement test that has been given to both groups. This shows that ABL is able to give effect for a 
longer period of time than conventional methods. The improvement of the thinking skills element takes time. Therefore, this process needs to be implemented continuously.

This study is expected to explicitly implicate students from the critical elements of critical thinking skills. This is in line with Malaysia's Mission and Appreciation that seeks to build a comprehensive human capital. This study also recommends other researchers to implement this $\mathrm{ABL}$ method by collecting data qualitatively or by mixed method.

\section{REFERENCES}

Anderson, T. N. (2014). Adventure programs 'effect on self-efficacy of business students' (Unpublished doctoral dissertation). ProQuest Dissertation and Theses Database, (UMI No. 3627695).

Azhari, M., \& Zaleha, I. (2013). Pengaruh Kompetensi Guru Matematik Ke Atas Amalan Pengajaran Kreatif. In 2nd International Seminar on Quality and Affordable Education (ISQAE 2013) (pp 181-187). 7-10 October 2013, Johor Baru, Johor

Berry, M. (2011). Learning and teaching in adventure education. In C. Hodgson, M. Berry (Ed.), Adventure education: An introduction (pp. 63-83). London: Routledge.

Beightol, J., Jevertson, J., Carter, S., Gray, S., \& Gass, M. (2012). Adventure education and resilience enhancement. Journal of Experiential Education, 35(2), 307-325. http://doi.org/10.5193/JEE35.2.307

Bunyan, P. (2011). Models and milestone in adventure education. In C. Hodgson, M. Berry (Ed.), Adventure Education: An Introduction (pp. 5-23). Abingdon: Routledge Taylor \& Francis Group.

Campbell, D. T., \& Stanley, J. C. (1963). Experimental and quasi-experimental designs for research. Boston: Houghton Mifflin Company.

Carrier, S. J., Tugurian, L. P., \& Thomson, M. M. (2013). Elementary science indoors and out: teachers, time, and testing. Research in Science Education, 43(5), 2059-2083. http://doi.org/10.1007/s11165-012-9347-5

Chua, Y. P (2006). Kaedah Penyelidikan Buku 1. Kuala Lumpur: Mc Graw Hill.

Cooley, S. J., Burns, V. E., \& Cumming, J. (2015). The role of outdoor adventure education in facilitating groupwork in higher education. Higher Education, 69(1), 567582. http://doi.org/10.1007/s10734-014-9791-4

Cooley, S. J., Holland, M. J. G., Cumming, J., Novakovic, E. G., \& Burns, V. E. (2014). Introducing the use of a semi-structured video diary room to investigate students' learning experiences during an outdoor adventure education groupwork skills course. Higher Education, 67(1), 105-121. http://doi.org/10.1007/s10734-013-9645-5

Cohen, L., Manion, L., \& Morrison, K. (2007). Research methods in education (6th ed.). Abingdon: Routledge Taylor \& Francis Group. 
Doering, A. (2006). Adventure learning: Transformative hybrid online education. Distance Education, 27(2), 197-215. http://doi.org/10.1080/01587910600789571

Doering, A. (2007). Adventure learning: Situating learning in an authentic context. Innovate, 3(6), article 4. Retrieved from http://publication/uuid/5D308F59-23E1-458ABB93-2D06D032E54C

Doering, A., \& Veletsianos, G. (2008). Hybrid online education: Identifying integration models using adventure learning. Journal of Research on Technology in Education (JRTE), 4l(1), 23-41. http://doi.org/Article

Fadhilah, S., Hamid, A., \& Mohamed, M. (2016). Experiential learning in the wilderness: Outdoor education program toward enhancing college students' leadership practices. 7th International Conference on University Learning and Teaching (InCULT 2014) Proceedings (pg. 525-535). http:// doi.org/10.1007/978-981-287-664-5

Ford, P. (1986) Outdoor education: Definition and philosophy. Las Cruses, NM: ERIC Clearinghouse on Rural Education and Small Schools.

Fraenkal, J. R., Wallen, N. E., \& Hyun, H. H. (2012). How to design and evaluate research in education (8th ed.). New York: McGraw-Hill. http://doi.org/ $10.1037 / 032719$

Gay, L.R., Mills, G.E., \& Airasian, P. (2009). Education research: Competencies for analysis and applications (9th ed.). New Jersey: Pearson Education.

Hans, T. A. (2000). A meta-analysis of the effects of adventure programming on locus of control. Journal of Contemporary Psychotherapy, 30(1), 33-60. http://doi.org/10.1023/A:1003649031834

Hattie, J., H. W. Marsh, Neill, J. T., \& Richards, G. E. (1997). Adventure education and outward bound: Out-of-class experience that make a lasting difference. Review of Educational Research, 67(1), 43-87.

Hodgson, C., \& Berry, M. (2011). Adventure education: An introduction. Abingdon: Routledge Taylor \& Francis Group.

Human, L. (2012). Adventure-based experiences during professional training in psychology: A follow-up study. South African Journal of Psychology, 42(4), 586-597.

Jackson, S. L. (2009). Research methods and statistics: A critical thinking approach (3rd ed.). Belmont: Wadsworth,cengage Learning.

Juriza, I., Ruzanna, Z., Harlina, H. S., Rohaizak, M., Zulkifli, Z., Fauzi, M. A., Radniwan, M., Razif, M., Heikal, M., Anisah, N., Nabishah, M., Lokman, S. (2011). Outdoor camps experiential learning activities for teamwork and leadership among medical students. Procedia - Social and Behavioral Sciences, 18, 622-625. doi:10.1016/j.sbspro.2011.05.091. 
Karppinen, S. J. A. (2012). Outdoor adventure education in a formal education curriculum in Finland: Action research application. Journal of Adventure Education \& Outdoor Learning, 12(1), 41-62. http://doi.org/10.1080/14729679. 2011.569186

Koh, L. L., Choy, S. K., Lai, K. L., Khaw, A. H., \& Seah, A. K. (2008). Kesan Pembelajaran Koperatif Terhadap Sikap Dan Pencapaian Matematik Bagi Murid-Murid Sekolah Rendah Di Sekitar Bandar Kuching. Jurnal Penyelidikan IPBL, 8, 50-64.

Larson, D. A. (2010). Adventure learning: Not everyone gets to play. In C. Honeyman, J. Coben, G. De Palo (Ed.), Venturing beyond the classroom: Volume 2 in the rethinking negotiation teaching series (pp. 201-216). Saint Paul: DRI Press.

Lee, D. P. (1997). The impact of an adventure-learning experience on team development using intact teams within a large federal agency: A quantitative and qualitative analysis (Unpublished doctoral dissertation). University of Maryland, Maryland.

Miller, B. G., Hougham, R. J., \& Eitel, K. B. (2013). The practical enactment of adventure learning: Where will you AL@? TechTrends, 57(4), 28-33. http://doi.org/10.1007/s11528-013-0674-9

Miller, C., Veletsianos, G., \& Doering, A. (2008). Curriculum at forty below: A Phenomenological inquiry of an educator/explorer's experience with adventure learning in the arctic. Distance Education, 29(3), 253-267. http://doi.org/10.1080/01587910802395789

Ministry of Education. (2013). Malaysia education blueprint 2013-2025. Ministry of Education: Putrajaya.

Mohd Afifi, B. S., Nor'ain, M. T., \& Mazlini, A. (2016). Walking, explore race and flying fox adventure activity in learning statistics: Effect on leadership skills. Jurnal Didaktik Matematika, 3(2), 1-8.

Mohd Afifi, B. S., Nor'ain, M. T., \& Mazlini, A. (2017). Adventure based learning module: content validity and reliability process. International Journal of Academic Research in Business and Social Sciences, 7(2), 615-623.

Mohd Taib, H., \& Norlena, S. (2010). Cultivating Personality Development Through Outdoor Education Programme: The Malaysia Experience. Procedia - Social and Behavioral Sciences, 9(2010), 228-234. http://doi.org/10.1016/j.sbspro.2010.12.141.

Novak, J. D. (1998). Learning, creating and using knowledge: Concept maps as facilitative tools in school and corporation. Hillsdale, New Jersey: Lawrence Erlbaum.

Paquette, L., Brassard, A., Guerin, A., Fortin-Chevalier, J., \& Tanguay-Beaudoin, L. (2014). Effects of a developmental adventure on the self-esteem of college students. Journal of Experiential Education, 37(3), 216-231. http://doi.org/10.1177/1053825913498372 
Rajendran, N. S. (2010). Teaching thinking skills at institutions of higher learning: lesson learned. Pertanika Jurnal of Social Sciences and Humanities, 18(S), 1-14.

Rhodes, H. M., \& Martin, A. J. (2013). Behavior change after adventure education courses: do work colleagues notice? Journal of Experiential Education, 37(3), 265-284. http://doi.org/10.1177/1053825913503115

Riggins, R. D. (1986). Effective learning in adventure-based education: setting directions for future research. Journal of Environmental Education, 18(1), 1-6. http://doi.org/10.1080/00958964.1986.9942722

Scrutton, R., \& Beames, S. (2013). Measuring the unmeasurable: Upholding rigor in quantitative studies of personal and social development in outdoor adventure education. Journal of Experiential Education, 38(1), 8-25. http://doi. org/10.1177/ 1053825913514730

Sibthorp, J., \& Jostad, J. (2014). The social system in outdoor adventure education programs. Journal of Experiential Education, 37(1), 60-74. http://doi.org/ 10.1177/1053825913518897

Sutherland, S., \& Stuhr, P. T. (2012). Reactions to implementing adventure-based learning in physical education. Sport, Education and Society, 19(4), 1-18. http://doi.org/10.1080/13573322.2012.688807

Veletsianos, G. (2010). A small-scale activity and its implications for higher education practice and research. Spring, 16(1), 89-104. Retrieve From http://ineducation.ca/article/small-scale-adventure-learning-activity-and-its-implicationshigher-education-practice-and-r

Veletsianos, G. (2012). Adventure learning. In N. Seel (Ed.), Encyclopedia of the sciences of learning (pp. 157-160). Springer Academic.

Veletsianos, G., \& Kleanthous, I. (2009). A review of adventure learning. International Review of Research in Open and Distance Learning, 10(6), 84-105.

Wan Nor Atiqah, \& Muzirah, M. (2016). Implementasi Kemahiran Berfikir Aras Tinggi (KBAT) Guru Matematik Sekolah Menengah Dalam Pengajaran Dan Pembelajaran Matematik. International Conference on Education Mathematics and Science (ICEMS 2016) in Conjunction with 4th International Postgraduate Conference on Science and Mathematics 2016 (IPCSM 2016). 19 November 2016, Universiti Pendidikan Sultan Idris, Tanjong Malim.

Weilbach, T., Meyer, C., \& Monyeki, M. (2011). The effect of adventure-based experiential learning on personal effectiveness of adolescents. African Journal for Physical, Health Education, Recreation and Dance, 16(4), 131-140. http://doi.org/10.4314/ajpherd.v16i4.64277

Yee, M. H., Jailani, M. Y., Widad, O., Razali, H., \& Tee, T. K. (2010). Penggunaan Kemahiran Berfikir Aras Tinggi Marzano Dalam Penjanaan Idea. In Seminar Majlis Dekan Pendidikan IPTA. 2-3 Ogos 2010, Hotel Concorde, Shah Alam. 
Yeo, S. M., \& Zhu, Y. (2005). Higher-Order thinking in Singapore mathematics classrooms. Retrieve from http://www.ibarian.net 